\title{
Developing Statistics Learning Equipment Based on the PMRI Approach Oriented to Students' Statistical Reasoning Ability
}

\author{
Nila Kesumawati ${ }^{1}$, Dina Octaria ${ }^{2}$ \\ ${ }^{1,2}$ Universitas PGRI Palembang; Email: nilakesumawati@yahoo.com
}

\begin{abstract}
This development research aims to produce valid, practical, and effectivelearning equipment. The developed learning equipmentincludesemester learning plans (RPS), student worksheets (LKM), and test questions in basic statistics courses using the PMRI approach oriented to statistical reasoning ability. This study employs the ADDIE development model. The quality of the product was assessed based on the validity, practicality, and effectiveness aspects. The result shows that the validity quality of the learning equipment has fulfilledthe valid criteria indicated by the average score of semester learning plans of 3.75 and the average score of the student worksheet of 3.70. The practicality of learning equipmenthas met the practical criteria indicated by the students' questionnaire responsesscore of 3.125 and the results of learning implementation observation of 90.17 . The effectiveness shows a score of $15 \%$ with low effective criteria, although based on the results of students' answers as a whole,the students' statistical reasoning is at level 3 (Procedural Reasoning).
\end{abstract}

Keywords: Development, Learning Equipment, PMRI, Statistic Reasoning

\section{INTRODUCTION}

In Basic Statistics courses, students are expected to be able to present data on research results in the form of raw or processed scores in an easy to be understood form. They are also expected to be able to generalize the object of research used as research samples. Students learnstatistical concepts or formula. In addition, they are also expected to be able to calculate and solve problems and can develop their reasoning ability. The reasoning is a process or an activity of thinking in connecting previous facts so that it could produce new correct conclusions.

Based on the result of observations during the learning, the lecturers rarely develop learning equipment such as Semester Learning Plans (RPS), and Student Worksheets (LKM). Based on the interview, many lecturers think that they do not have enough time to develop the LKM. The RPS they develop is rarely adjusted to the development of science according to the conditions of the field of study. Those conditions push the lecturers to strive for planning the learning activities that allow students to develop statistical reasoning abilities and maximize learning outcomes.

One effort to overcome the problem that arises is to develop learning equipment for basic statistics courses based on the PMRI approach oriented to students' statistical reasoning ability. PMRI is one approach in mathematics learning based on the view that mathematics as a human activity.Students are not seen as passive recipients of mathematics. They are given the opportunity to rediscover mathematics under adult supervision. There are four stages of developing realistic mathematics learning models, namely: 1) the stage of the real or contextual situation, statistics are closely related to contextual problems 2) reference stage, 3) generalization stage, 4) formal stage. Therefore, in developing learning equipment, an approach is needed to fit the conditions and needs of the students. 
Several studies have been carried out to develop learning equipment in the form of semester learning plans (RPS), student worksheets (LKM), and other forms of learning (Andari \& Lusiana, 2014; Asmawati \& Wuryanto, 2014; Febriana, Sulur, \& Yudyanto, 2014; Fitri, 2011; Hartono \& Noto, 2017; Indraningtias, Diah, \& Ariyadi Wijaya, 2017; Melisa, 2016; Nisak, 2013; Rizkiah, Nasir, \& Komarudin, 2018; Rudiono, Dafik, \& Wahyuningrum, 2015; A. U. Sari, Farida, \& Putra, 2017; F. K. Sari, Farida, \& Syazali, 2016; Sulistyowati \& Sugiman, 2014; Supiyati \& Jailani, 2014; Supriadi, Farida, \& Lestari, 2018; Susanti, Musdi, \& Syarifuddin, 2017; Wijayanti \& Sungkono, 2017; Yusnita \& Subanti, 2014) and use realistic approach or PMRI (Ayunika et al., 2011; Bey \& Asriani, 2013; Putra, 2016; Syahputra, 2013; Wijaya, 2012). However, no previous research has developed learning equipment in the form of semester learning plans (RPS), student worksheets (LKM), and test questions in basic statistics course using the PMRI approach oriented to statistical reasoning ability.

Based on previous research, renewability in this study lies in the development of learning equipment in the form of semester learning plans (RPS), student worksheets (MFIs), and test questions in basic statistics course using the PMRI approach oriented to statistics reasoning ability. So, the purpose of this study is to produce valid, practical and effective learning equipment in basic statistics course using the PMRI approach oriented to statistical reasoning ability.

\section{THE RESEARCH METHODS}

The method used in this study is development research that refers to the ADDIE model proposed by Dick and Carry (Mulyatiningsih, 2012). The development stage consists of 5 stages, namely analysis, design, development, implementation, and evaluation. Data collecting techniques used were assessment sheets of the learning equipment, questionnaires, learning implementation feasibility sheets, and tests. The data analysis was conducted to obtain an overview of the productto determine the quality of learning equipment in terms of validity, practicality, and effectiveness.

The data used in the validity analysis is the data from the assessment of the learning equipment by the lecturers as the experts while the practicality analysis is the students' responses of the questionnaires, and lastly the learning observation. In the validity analysis, the results of the assessment were analyzed by (1) Tabulating the assessment score of the learning equipment by grouping the statement items according to the observed aspects. (2) Determining the average score. (3) Converting the average score into a qualitative score by comparing it to the assessment criteria in Table 1. (Widyoko \& Puto, 2009)

Table 1. Conversion Guidelines in Converting the Average Score into Qualitative Data

\begin{tabular}{cc}
\hline Interval Average Score & Criteria \\
\hline $3,4<\bar{x} \leq 4,0$ & Highly Valid \\
\hline $2,8<\bar{x} \leq 3,4$ & Valid \\
\hline $2,2<\bar{x} \leq 2,8$ & Quite Valid \\
\hline $1,6<\bar{x} \leq 2,2$ & Less Valid \\
\hline $1,0 \leq \bar{x} \leq 1,6$ & Invalid \\
\hline
\end{tabular}


The students' responses questionnaire analysis was carried out using the same steps as the validity analysis with the assessment criteria in Table 22 (Widyoko \& Puto, 2009)

Table 2. Conversion Guidelines in Converting the Average Score into Qualitative Data

\begin{tabular}{cc}
\hline Interval Average Score & Criteria \\
\hline $3,4<\bar{x} \leq 4,0$ & Highly Practical \\
\hline $2,8<\bar{x} \leq 3,4$ & Practical \\
\hline $2,2<\bar{x} \leq 2,8$ & Quite Practical \\
\hline $1,6<\bar{x} \leq 2,2$ & Less Practical \\
\hline $1,0 \leq \bar{x} \leq 1,6$ & Impractical \\
\hline
\end{tabular}

Analysis of the learning implementation observation sheet is to calculate the number of observers who choose the "yes" option and then calculate the percentage, after that, compare the responses with the assessment criteria. The criteria for evaluating the implementation of learning are presented in Table 3

Table 3. Criteria for Evaluating the Implementation of Learning

\begin{tabular}{cc}
\hline Intervals Percentage of & Criteria \\
\hline$p \geq 85 \%$ & Highly Practical \\
\hline $7005 \leq p<85 \%$ & Practically \\
\hline $50 \% \leq p<70 \%$ & Quite Practical \\
\hline$p<50 \%$ & Less Practical \\
\hline
\end{tabular}

Analysis of effectiveness was obtained from the results of tests of students' statistical reasoning ability. The analysis was carried out in the following ways: (1) determining the learning outcome test score based on the assessment guidelines, (2) determining the percentage of the number of students who have a score greater than or equal to 70, (3) comparing the percentages with the criteria for evaluating effectiveness. The criteria used are presented in Table 4. (Widyoko \& Puto, 2009)

Table 4. Criteria for Evaluating Academic Skills

\begin{tabular}{cc} 
Percentage & Classification \\
\hline$p>80$ & Highly Effective \\
\hline $60<p \leq 80$ & Effective \\
\hline $40<p \leq 60$ & Quite Effective \\
\hline $20<p \leq 40$ & Less Effective \\
\hline$\leq 20$ & Ineffective \\
\hline
\end{tabular}

Description:

P: The percentage of the numbers of students who qualify. 


\section{THE RESULTS OF THE RESEARCH AND THE DISCUSSION}

The learning equipment development model used in this study is the ADDIE model which includes analysis, design, development, implementation, and evaluation stages.

\section{A. Analysis Stage}

The analysis stages were conducted in the development of learning equipment, namely (1) needs analysis. At this stage, the information obtained was that the student worksheet rarely developed by the lecturer, the lack of time in developing the student worksheet, and the student worksheet already developed is rarely adjusted to the development of science, especially in the field of science studied by the students. (2) Curriculum analysis,this analysis was carried out based on the KKNI (National Qualification Framework), especially the CPL of Study Program, CP MK, and learning indicators for Basic Statistics courses. (3) Analysis of students' characteristics, academic ability, and students' learning motivation. The students' levels were varied in terms of understanding and motivation. They tended to be saturated in learning statistical subjectssince there are many calculation formulas. On the other hand, the students were more interested in apperception given in the form of familiar events in real life which they had experienced or known.

\section{B. Design Stage}

The next step after the analysis stage is the design stage which consists oflearning equipmentthat covers: (1) RPS compilation, which is carried out to determine the component, learning outcome, materials and references, and the learning process assessment techniques using the PMRI approach. (2) The preparation of the LKMwas carried out to compile the needs toward the LKM, determine the framework of the LKM that contains titles and subtitles, and collect various references and design of the LKM. (3) Preparation of instruments was carried out to assess the quality of learning equipment. There are four developed instruments, namely the learning equipment assessment sheet in the form of RPS assessment sheet, LKM assessment sheet, student questionnaire, learning implementation observation sheet, and questions of statistical reasoning ability.

\section{Development Stage}

At this stage of development, the researcher developed the learning equipment in the form of RPS, LKM, and instruments based on the framework design obtained at the design stage.

\section{Development of RPS}

RPS was developed with reference to Permenristekdikti (The Regulation of the Ministry of Education) No. 44 of 2015 and in accordance with the design at the design stage. The RPS was prepared for one semester (16 meetings, including the mid-term test and end of the semester test). A special feature of the PMRI approach is oriented towards statistical reasoning abilities for core activities as follows:

a. Lecturers provide "real world" problems or problems that are considered real presented in LKM.

b. Lecturers, direct students to solve problems by answering questions that can construct students' statistical reasoning ability. 
c. The lecturers direct the students to be able to give conclusions or to be able to do mathematics.

d. Lecturers provide opportunities for students to present the work of each group and to condition the students to interact.

e. The lecturers conduct confirmation activities and enrich the material in an integrated manner.

\section{The Development of LKM}

The LKM was developed by referring to the steps of development by the Ministry of National Education in 2008 and in accordance with the design at the design stage. The LKM were arranged for one semester with the characteristics to developthe students' ability. The developed LKM was used to measure students' statistical reasoning ability with the PMRI approach. The following is an example of the layout of the developed LKM.

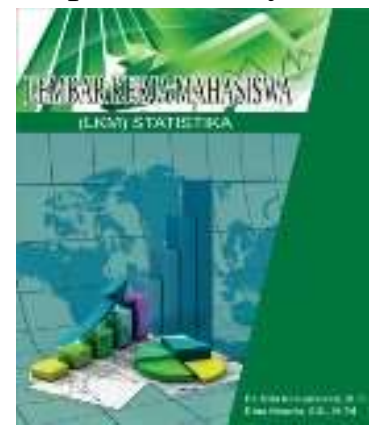

Figure 1. The Cover of the LKM

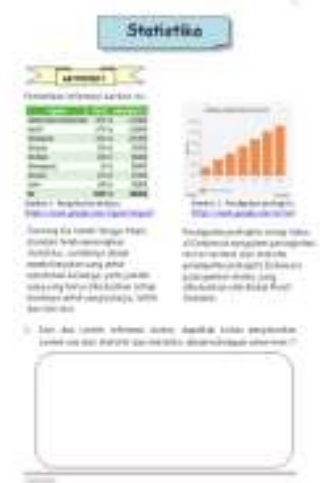

Figure 2. The Display of Problems in the LKM

\section{Preparation of Instrument}

The instrument was developed in accordance with the design at the design stage. In addition, the key answer for the lecturer was also developed.

4. Validation

The RPS and LKM were validated by 5 validators. To be precise, the validators consisted of 2 material experts and 3 mathematics lecturers. Some of the comments from the validators are presented in Table 5. 
Table 5. The Suggestionsfrom the Validators

\begin{tabular}{|c|c|c|c|}
\hline No. & Before & Suggestions & After \\
\hline 1 & $\begin{array}{l}\text { The objectives of the } \\
\text { LKM 1: } \\
\text { 1. Understand the } \\
\text { definition of } \\
\text { statistics. } \\
\text { 4. Understand the } \\
\text { basic concepts of } \\
\text { statistics } \\
\text { (population, } \\
\text { samples, } \\
\text { variables, } \\
\text { rounding of data, } \\
\text { sigma notation, } \\
\text { and Greek } \\
\text { alphabet) }\end{array}$ & $\begin{array}{l}\text { Use operational verbs so that } \\
\text { they can be measured (the word } \\
\text { understand should be changed } \\
\text { into explaining) }\end{array}$ & $\begin{array}{l}\text { The objectivesNumber: } \\
\text { 1. Explain the definition of } \\
\text { Statistics. } \\
\text { 4. Explain the basic concepts } \\
\text { of statistics (population, } \\
\text { sample, variable, rounding } \\
\text { of data, sigma notation, and } \\
\text { Greek alphabet) }\end{array}$ \\
\hline 2 & $\begin{array}{l}\text { The objectives of } \\
\text { LKM } 2 \text { consist of six } \\
\text { objectives and three } \\
\text { activities }\end{array}$ & $\begin{array}{l}\text { The seventh point is added to } \\
\text { the objectives of MFI } 2\end{array}$ & $\begin{array}{l}\text { After studying the LKM 2, you } \\
\text { will be able to: } \\
\text { 1. Benefit from presenting data. } \\
\text { 2. Various ways of presenting } \\
\text { data (graphs and tables) } \\
\text { 3. Presenting data in the form of } \\
\text { diagrams (bar charts, lines, } \\
\text { circles, and branches and } \\
\text { leaves). } \\
\text { 4. Know the parts of a } \\
\text { frequency distribution. } \\
\text { 5. Make a frequency } \\
\text { distribution table. } \\
\text { 6. Know the types of a } \\
\text { frequency distribution } \\
\text { (relative frequency } \\
\text { distribution and cumulative } \\
\text { frequency distribution). } \\
\text { 7. Presenting data in graphical } \\
\text { form (histogram, polygon, } \\
\text { and Ogive). }\end{array}$ \\
\hline 3 & $\begin{array}{l}\text { Activity } 3 \\
\text { Questions number } 2 \text {, } \\
\text { 3, and 4: the task on } \\
\text { these questions uses } \\
\text { data in question } \\
\text { number 1. }\end{array}$ & $\begin{array}{l}\text { The third activity is changed to } \\
\text { the first activity. } \\
\text { Avoid using words related to } \\
\text { the previous question. }\end{array}$ & $\begin{array}{l}\text { The following is the data from } \\
\text { the research results of a linear } \\
\text { Algebra subject from } 40 \\
\text { students: } 24,18,11,10,20,10, \\
18,17,18,15,14,12,10,15, \\
20,11,14,23,18,16,20,21, \\
10,14,20,25,15,18,26,12, \\
14,16,13,19,21,19,18,17, \\
12,26 .\end{array}$ \\
\hline 4 & $\begin{array}{l}\text { Activity } 2 \\
\text { Problem number } 3 \\
\text { Problem number } 4\end{array}$ & $\begin{array}{l}\text { Unnecessary and should be } \\
\text { omitted. } \\
\text { Show the data. } \\
\text { Show the group data. }\end{array}$ & Problem number 3 is omitted. \\
\hline
\end{tabular}




\begin{tabular}{|c|c|c|c|c|}
\hline No. & Before & Suggestions & \multicolumn{2}{|c|}{ After } \\
\hline \multirow[b]{9}{*}{5} & \multirow[t]{8}{*}{ Problem number 5} & & $\begin{array}{l}\text { Questions nun } \\
\text { display data in }\end{array}$ & and 5 \\
\hline & & & $\begin{array}{l}\text { Learning } \\
\text { outcomes }\end{array}$ & $\mathrm{F}$ \\
\hline & & & $40-49$ & 1 \\
\hline & & & $50-59$ & 2 \\
\hline & & & $60-69$ & 2 \\
\hline & & & $70-79$ & 5 \\
\hline & & & $80-89$ & 9 \\
\hline & & & $90-99$ & 1 \\
\hline & Let's practice & Revise problem number 2. & $\begin{array}{l}\text { If } D_{5} \text { from the } \\
\text { is } 59.5 \text { with } D_{5} \\
50-59 \text {. }\end{array}$ & $\begin{array}{l}\text { he table } \\
\text { erval of }\end{array}$ \\
\hline
\end{tabular}

\section{Revision}

After validation, there were several revisions for the learning equipment. The learning equipmentwas then revised according to the suggestions and input from the validators.

\section{Implementation Stage}

At this stage, several activities were implemented, namely the learning equipmenttryout, the students' statistical reasoning ability test, and the questionnaire responses of lecturers and students. Learning equipment that had been validated and revised was then tested. The tryout of the learning equipmentwas carried out at the University of PGRI Palembang to the 80second semester students in February - June 2018.

\section{E. Evaluation Stage}

The final stage in the development of learning equipment is evaluation. There were several revisions that were used as suggestions for improvement or revision forstage II. In addition, at this stage, the quality of the learning equipment was also analyzed.

1. Validity Analysis

The validity analysis was carried out to determine the validity of the learning equipment that was developed based on the assessment by the validators. The following are the results of the assessment of the learning equipment reviewed from the aspect of validity. The results of the assessment are presented in tables 6 and 7 in sequence. 
Table 6. RPS Quality Assessment Results

\begin{tabular}{clcc}
\hline No & \multicolumn{1}{c}{ Assessment Aspects } & Average Score & Criteria \\
\hline 1 & Course Identity & 3.85 & Highly Valid \\
2 & Formulation of Learning Outcomes & 3.67 & Highly Valid \\
3 & Relevance of Material & 3.95 & Highly Valid \\
4 & Lecture Methods & 3.50 & Highly Valid \\
5 & Lecture Activities & 3.67 & Highly Valid \\
6 & Selection of Learning Resources / Media & 3.80 & Highly Valid \\
7 & Assessment of Learning Outcomes & 3.73 & Highly Valid \\
8 & Language & 3.80 & Highly Valid \\
& $\quad$ Average Score & $\mathbf{3 . 7 5}$ & Highly Valid \\
\hline
\end{tabular}

Table 7. LKM Quality Assessment Results

\begin{tabular}{clcc}
\hline No & \multicolumn{1}{c}{ Aspect } & Average Score & Criteria \\
\hline 1 & Material Quality & 3.78 & Very Valid \\
2 & Conformity with Didactic Terms & 3.63 & Very Valid \\
3 & Conformity with Construction Terms & 3.90 & Very Valid \\
4 & Compliance with Technical Requirements & 3.50 & Very Valid \\
& Average Score & $\mathbf{3 . 7 0}$ & Highly Valid \\
\hline
\end{tabular}

Based on the average scores, the validity is in the highly valid criteria. Valid learning equipment is needed so that the learning process can run well. This is in accordance with Permendiknas (The Regulation of the Ministry of National Education) No. 41 of 2007 which states that teachers are obliged to develop learning equipment in full so that learning could be interactive, inspiring, fun, challenging, and motivating in order for the students to be able to actively participate and providing sufficient space for initiative, creativity, and independence in accordance with the talents, interests, and physical and psychological development.

\section{Practicality Analysis}

Assessment of practicality of learning equipment based on student questionnaires and observations of learning implementation.

a) Students' QuestionnaireResponses

The assessment was conducted to 80 students to assess the learning equipment developed from aspects of assistance and aspects of convenience.

Table 8. The Results of Students' Questionnaire Responses

\begin{tabular}{cccc}
\hline No & Aspects Assessed & Average Score & Criteria \\
\hline 1 & Assistance & 3.17 & Practical \\
\hline 2 & Convenience & 3.08 & Practical \\
\hline & Average score & $\mathbf{3 . 1 2 5}$ & Practical \\
\hline
\end{tabular}

Based on the average score of 3.125 , the practical criteria are obtained. 
b) The Results of Learning Implementation Observation

The results of the observation sheet are presented in Table 9.

Table 9. The Results of Learning Implementation Observation

\begin{tabular}{ccc}
\hline Meeting & Percentage & Criteria \\
\hline 1 & $100 \%$ & Highly Practical \\
2 & $100 \%$ & Highlypractical \\
3 & $84 \%$ & Practical \\
4 & $79 \%$ & Practical \\
5 & $89 \%$ & Highly practically \\
6 & $89 \%$ & practical \\
Average & $\mathbf{9 0 . 1 7 \%}$ & Highly practical \\
\hline
\end{tabular}

Based on the average score in Table 9, the highly practical criteria are obtained. Based on the students' questionnaireresponses and the observations, it is discovered that the learning equipmenthas fulfilled the practical requirements for learningequipment. This is consistent with research by Aminah who says that the learning equipment is said to be practical if after the test in the experimental class has been conducted, positive responses from the learners and the teachers as well as the classroom management using the learning equipmentare obtained.(Aminah, 2016)

3. The Analysis of Effectiveness

The effectiveness can be seen from the results of students' statistical reasoning abilitytest. The data from the test shows that the students who achieved the criteria ofminimum competence (KKM) are greater than 70 as obtained by 12 out of 80 students.

$$
\begin{gathered}
\mathrm{K}=\frac{\text { The number of students who pass }}{\text { the number of test takers }} \times 100 \% \\
\mathrm{~K}=\frac{12}{80} \times 100 \%=15 \%
\end{gathered}
$$

Thus, the percentage of student completeness is $15 \%$ so that the effectiveness is in the less effective criteria.

The research results obtained from the development of this learning equipment are slightly different from the previous research conducted by other researchers who stated that the learning equipment based on the PMRI approach produced in previous studies, based on the try-out, reached the highly valid and practicalcriteria with the percentage of $75 \%$ (Yuliana, 2017). In this study, the statistics learning equipment based on the PMRI approach oriented to statistical reasoning abilities have met highly valid and practical criteria although for the effectiveness is only $15 \%$ with less effective criteria. However, based on the results of students' answers as a whole, it was found that the statistical reasoning of students is at level 3 (Procedural Reasoning).The students could apply the concept correctly to solve the problem but could not interpret and relate it to the original problem (making conclusions). This means that based on the level, students' statistical reasoning ability is good. 
In the learning process in the classroom, students generally look activeand enthusiastic so thatlearning using the developed learning equipment can be said to run smoothly. However, the students have difficulty in completing test questions on statistical reasoning ability. This can be seen from the results of the students' answers. One of the student answers is presented in the image below.

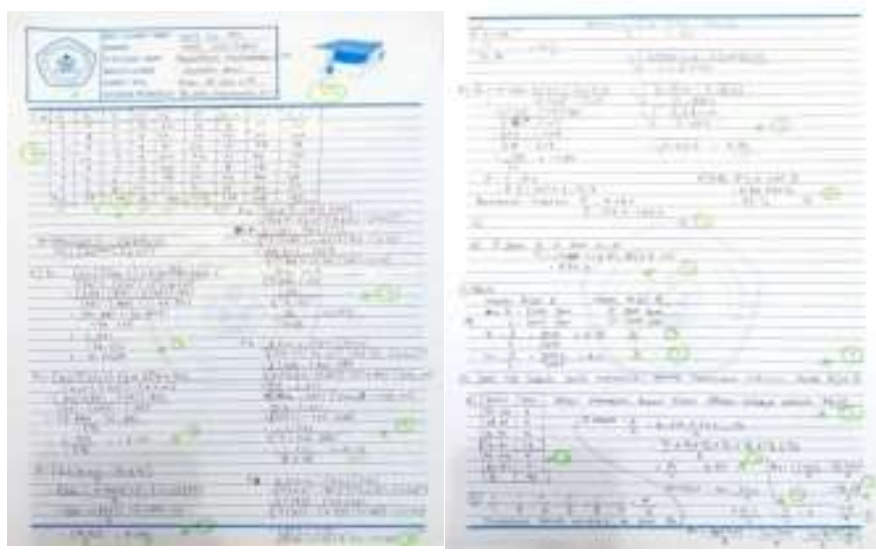

Figure 3. The Answers of Student Evaluation

Based on the results of one of the student's answer, it appears that he is able to present and process data in question no. 1a, 1b, 1d, 1e, 3a and questions no. 4 but there are still some errors in the calculation. For question no. 1c, hewas not been able to provide an explanation correctly.For question no. $3 \mathrm{~b}$, he is only able to draw conclusions without expressing arguments and giving critical comments. The results of the student's answers above show that the student's statistical reasoning abilities are already at level 3. The difficulty in making conclusions and explaining arguments is because they are not used to expressing arguments. In fact, in learning, the students need to be accustomed to providing arguments for each answer and giving responses to the answers given by others so that what is learned becomes more meaningful for them.

Some of the factors that cause low learning effectiveness are: 1) Basic Statistics course is taught in the second semester so the students forget a lot of the material learned during high school, 2) Statistical ability measured at high school is limited to data presentation and processing ability without expressing arguments, drawing conclusions and providing comment, 3 ) the students have difficulty in giving reasons for the correctness of solutions and drawing conclusions. This is in line with Maryati and Priatna's research stating that there are 7 types of student difficulties in statistics material in terms of reasoning ability and statistical communication,(Maryati \& Priatna, 2017) 4) the students still consider statistics as a difficult subject as can be seen from the results of interviews with the students even though the results of the interviews are not used as data collection techniques.

Based on previous research by Wibowo, the PMRI approach has an effective influence on reasoning abilities. (Wibowo, 2017) and also research by Yuliana and Sari who state that the PMRI approach has a good influence on learning completeness (Yuliana, 2017). 


\section{CONCLUSION AND SUGGESTION}

Based on data analysis, it is concluded that the developed learning equipmenthas met valid criteria and practical criteria although the effectiveness score is only $15 \%$ with less effective criteria. However, based on the results of students' answers as a whole, it is known that the students' statistical reasoning ability is at level 3 (Procedural Reasoning).

The suggestions related to the results and findings of this study are for lecturers who teach statistics. The basic statistics from the beginning should have familiarized students by providing statistical questions to measure students' statistical reasoning ability.For other researchers, based on the results of the study, it is found that the Student's statistical reasoning ability is at level 3 (Procedural Reasoning) so that the next research should be focused on the level 4 statistical reasoning ability (Integrated Reasoning).

\section{REFERENCES}

Aminah, N. (2016). Kepraktisan Model Assurance, Relevance, Interest, Assessment, Satisfaction (ARIAS) Pada Pembelajaran Matematika. Journal of Mathematics Education AlphaMath, 2(2).

Andari, T., \& Lusiana, R. (2014). Pengembangan Perangkat Pembelajaran Dengan Menggunakan Pendekatan Quantum Learning Berbasis Needs Assesment Pada Materi Ruang-n Euclides. Jurnal Ilmiah Pendidikan Matematika, 3(1), 1-10.

Asmawati, R., \& Wuryanto. (2014). Keefektifan Model Pembelajaran LC 5E Dan TSTS Berbantuan LKPD Terhadap Hasil Belajar. Jurnal Kreano, 5(1), 26-32.

Ayunika, E., Sari, P., Studi, P., Matematika, P., Sanata, U., \& Yogyakarta, D. (2011). Pengembangan Hipotesis Trayektori Pembelajaran Untuk Konsep Pecahan. In Matematika dan Pendidikan Karakter dalam Pembelajaran (pp. 206-212).

Bey, A., \& Asriani. (2013). Penerapan Pembelajaran Problem Solving untuk Meningkatkan Aktivitas dan Hasil Belajar Matematika pada Materi SPLDV. Jurnal Pendidikan Matematika, 4(2), 223-239.

Febriana, L. C., Sulur, \& Yudyanto. (2014). Pengembangan Lembar Kerja Siswa (LKS) Fisika Materi Tekanan Mencakup Ranah Kognitif, Afektif dan Psikomotor Sesuai Kurikulum 2013 untuk Siswa SMP/MTs. Jurnal Universitas Negeri Malang, 2(1), 1-12.

Fitri, A. (2011). Pengembangan Perangkat Pembelajaran Statistika Dasar Bermuatan Pendidikan Karakter Dengan Metode Problem Based Learning. Jurnal PP, 1(2), 159-165.

Hartono, W., \& Noto, M. S. (2017). Pengembangan Modul Berbasis Penemuan Terbimbing untuk Meningkatkan Kemampuan Matematis pada Perkuliahan Kalkulus Integral. Jurnal JNPM ( Jurnal Nasional Pendidikan Matematika ), 1(2), 320-333.

Indraningtias, A., Diah, \& Ariyadi Wijaya. (2017). Pengembangan Perangkat Pembelajaran Berbasis Pendekatan Matematika Realistik Materi Bangun Ruang Sisi DatarBerorientasi Pada Kemampuan Berpikir Kritis Siswa Kelas VIIISMP. Jurnal Pendidikan Matematika, $6(5), 1-10$. 
Maryati, I., \& Priatna, N. (2017). Analisis Kesulitan dalam Materi Statistika Ditinjau dari Kemampuan Penalaran dan Komunikasi Statistis. Jurnal Prisma, 6(2).

Melisa. (2016). Pengembangan Modul Berbasis Penemuan Terbimbing Yang Valid Pada Perkuliahan Kalkulus Peubah Banyak 1. LEMMA, 1(2), 21-27.

Mulyatiningsih, E. (2012). Metode Penelitian Terapan Bidang Pendidikan. Bandung: Alfabeta.

Nisak, K. (2013). Pengembangan Perangkat Pembelajaran IPA Terpadu Tipe Connected pada Materi Pokok Sistem Ekskresi untuk kelas IX SMP. Jurnal Pendidikan Sains, 1(1), 8184.

Putra, F. G. (2016). Pengaruh Model Pembelajaran Reflektif dengan Pendekatan Matematika Realistik Bernuansa Keislaman terhadap Kemampuan Komunikasi Matematis. Al-Jabar: Jurnal Pendidikan Matematika, 7(2), 203-210.

Rizkiah, A. W., Nasir, \& Komarudin. (2018). LKPD Discussion Activity Terintegrasi Keislaman dengan Pendekatan Pictorial Riddle pada Materi Pecahan. Desimal : Jurnal Matematika, 1(1), 39-47.

Rudiono, T., Dafik, \& Wahyuningrum, E. (2015). Pengembangan Perangkat Pembelajaran Berbasis Rme Berorientasi Terciptanya Berfikir Tingkat Tinggi Materi Perbandingan Kelas VII. Pancaran, 4(1), 45-54.

Sari, A. U., Farida, \& Putra, F. G. (2017). Pengembangan Media Pembelajaran Berbantuan Web Dengan Pendekatan Etnomatematika Pada Pokok Bahasan Bangun Ruang Sisi Datar. In Prosiding Seminar Nasional Matematika dan Pendidikan Matematika (pp. 209-214). Lampung.

Sari, F. K., Farida, \& Syazali, M. (2016). Pengembangan Media Pembelajaran (Modul) berbantuan Geogebra Pokok Bahasan Turunan. Al-Jabar: Jurnal Pendidikan Matematika, $7(2), 135-151$.

Sulistyowati, Y., \& Sugiman. (2014). Pengembangan Perangkat Pembelajaran Bangun Ruang di SMP dengan Pendekatan Creative Problem Solving. Phytagoras, 9(2), 219-232.

Supiyati, \& Jailani. (2014). Pengembangan Perangkat Pembelajaran Bangun Ruang SMP dengan Pendekatan SAVI ( Somatik, Auditori, Visual, Intelektual). Jurnal Pendidikan Matematika, 9(2), 175-185.

Supriadi, N., Farida, \& Lestari, B. D. (2018). Pengembangan Modul Kalkulus Pada Materi Turunan Bernuansa Keislaman dengan Pendekatan Penemuan Terbimbing. In YSSTEE International Conference (pp. 1-11).

Susanti, Musdi, E., \& Syarifuddin, H. (2017). Pengembangan Perangkat Pembelajaran Matematika Materi Statistik Berbasis Penemuan Terbimbing Untuk Meningkatkan Kemampuan Pemecahan Masalah Matematis Materi Statistika. Jurnal JNPM ( Jurnal Nasional Pendidikan Matematika ), 1(2), 305-319.

Syahputra, E. (2013). Peningkatan Kemampuan Spasial Siswa Melalui Penerapan Pembelajaran Matematika Realistik. Cakrawala Pendidikan, 32(3), 353-364. 
Wibowo, A. (2017). Pengaruh Pendekatan Matematika Realistik dan Saintifik Terhadap Prestasi Belajar, Kemampuan Penalaran Matematis dan Minat Belajar. Jurnal Riset Penelitian Matematika, 4(1), 1-10〉.

Widyoko, \& Puto, S. E. (2009). Evaluasi Program Pembelajaran:Panduan Praktis bagi Guru dan Calon Pendidik. Yogyakarta: Pustaka Belajar.

Wijaya, A. (2012). Pendidikan Matematika Realistik: Suatu Alternatif Pendekatan Pembelajaran Matematika. Yogyakarta: Graha Ilmu.

Wijayanti, S., \& Sungkono, J. (2017). Pengembangan Perangkat Pembelajaran mengacu Model Creative Problem Solving berbasis Somatic, Auditory, Visualization, Intellectually. AlJabar: Jurnal Pendidikan Matematika, 8(2), 101-110.

Yuliana, R. (2017). Pengembangan Perangkat Pembelajaran Dengan Pendekatan PMRI Pada Materi Bangun Ruang Sisi Lengkung untuk SMP Kelas IX. Jurnal Pendidikan Matematika, 6(1), 60-67.

Yusnita, R., \& Subanti, S. (2014). Pengembangan Perangkat Pembelajaran Berbasis Penemuan Terbimbing (Guided Discovery) Dengan Pendekatan Somatic, Auditory, Visual, Intellectual (SAVI) Pada Materi Pokok Peluang Kelas IX SMP Tahun Pelajaran 2013/2014. Jurnal Elektronik Pembelajaran Matematika, 2(4), 379-388. 